\title{
CANALICULAR INFECTION CAUSED BY ACTINOMYCES
}

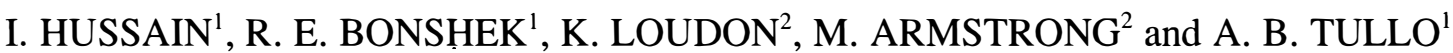 \\ Manchester
}

\begin{abstract}
SUMMARY
We present 7 cases of canalicular involvement with Actinomyces collected over a 5-year period. All patients had involvement of one canaliculus, upper or lower, with lacrimal drainage patent to syringing. Curettings obtained by incising the involved canaliculi yielded Actinomyces species (5 cases) and Arachnia propionica ( 2 cases), typically in association with a mixed bacterial growth. Our results show that these patients often remain undiagnosed for months or even years, and are treated inappropriately for their recurrent symptoms. Despite sensitivity of Actinomyces to a broad spectrum of antibiotics, medical therapy alone does not eradicate the disease, and surgical evacuation of all concretions is essential to achieve a cure.
\end{abstract}

The generic name Actinomyces was first used by Harz in $1879^{1}$ to describe organisms seen in lesions of cattle. They occurred as masses that resembled fungal mycelia; these mycelia were arranged in a radial pattern, hence the name Actinomyces (ray fungus).

Infections of the eye with this organism have been described in the literature under a variety of names such as streptotrichosis, leptotrichosis and actinomycosis. Actinomyces species are now recognised as gram-positive bacilli which can occur singly, in pairs or in chains and are nonacid-fast, non-motile, obligate or facultative anaerobes. Characteristically they are seen as branching filaments on gram staining. They are members of the bacterial flora of both man and animals and normally exist in a commensal relationship with their host, growing particularly on teeth and other surfaces in the oral cavity including the tonsils. Chronic granulomatous infections involving various parts of the body can occur and spread is usually by direct extension, producing sinus tracts and characteristic sulphur granules.

Various forms of ocular infection by Actinomyces have been described: conjunctivitis, canaliculitis, lacrimal sac involvement, keratitis and endophthalmitis. ${ }^{2-7}$ We report 7 cases of canaliculitis caused by these organisms, and emphasise how easily the diagnosis may be overlooked.

From: 'Royal Eye Hospital, Manchester; ${ }^{2}$ Manchester Royal Infirmary, Manchester, UK.

Correspondence to: Mr. A. B. Tullo, Consultant Ophthalmologist, Royal Eye Hospital, Oxford Road, Manchester M13 9WH, UK.

\section{PATIENTS AND METHODS}

Of 7 patients presenting between 1988 and 1992, 2 were male and 5 female (Table I); 4 were affected on the left side and 3 on the right; 4 had lower canalicular and 3 had upper canalicular involvement (Figs. 1,2). In all patients syringing of the lacrimal drainage system on the affected side proved patent before surgery. The diagnosis was confirmed by bacteriological examination of the concretions (Fig. 3). These were obtained by incising the canaliculi onto a probe with a blade, or by directly introducing one blade of a fine scissor and cutting the canaliculus. The organisms were isolated by culturing the specimen anaerobically on $7.5 \%$ horse blood columbia agar plates (Oxoid, Basingstoke, UK) for up to 5 days. Enrichment culture in Fastidious Anaerobic Broth (Lab M, Bury, UK) was also carried out.

Identification of Actinomyces was by gram film (Fig. 4) and biochemical profile using ATB 32 A (bioMerieux, Basingstoke, UK). The profiles obtained for Actinomyces israelii, Actinomyces meyeri and Arachnia propionica all gave excellent identification. Sensitivity testing was by the disc diffusion method on blood agar plates incubated anaerobically.

\section{RESULTS}

Before surgery was performed, 6 of 7 patients were treated with various antibiotics (Table I). The antibiotics used, either topically or systemically, were generally effective against Actinomyces even when actinomycosis was not considered in the differential diagnosis. Only in 2 cases at a later date was specific treatment for Actinomyces started before surgery. Typically this produced a temporary improvement, after which symptoms recurred.

Actinomyces species were grown from 5 of our cases and Arachnia propionica (a related genus within the Actinomycetales) from the remaining 2 cases. All except one of the surgical specimens we obtained yielded other organisms in addition to Actinomyces species (Table II).

\section{DISCUSSION}

All our patients presented with a history of chronic irritation and discharge or/and epiphora. Only 5 patients had a canalicular swelling on presentation, the other 2 developing it during the course of their disease. The disease 
Table I. Patients with Actinomyces canaliculitis

\begin{tabular}{|c|c|c|c|c|}
\hline Patient no. & Sex/age (yr) & $\begin{array}{l}\text { No. of } \\
\text { visits }\end{array}$ & Treatment prior to surgery ${ }^{b}$ & $\begin{array}{l}\text { Time between 1st } \\
\text { visit and op. (months) }\end{array}$ \\
\hline 1 & $\mathrm{~F} / 24$ & 2 & Ampicillin (oral) & 4 \\
\hline 2 & $\mathrm{~F} / 56$ & 6 & $\begin{array}{l}\text { Chloramphenicol (top.), septrin (oral), tetracycline } \\
\text { (oral + top.) }\end{array}$ & 2 \\
\hline 3 & $\mathrm{~F} / 29$ & 3 & $\begin{array}{l}\text { Chloramphenicol (top.) (listed for incision } \\
\text { and curettage of cyst) }\end{array}$ & 8 \\
\hline 4 & $\mathrm{M} / 63$ & 10 & $\begin{array}{l}\text { Ampicillin (oral), chloramphenicol (top.), } \\
\text { tetracycline (oral + top.) }\end{array}$ & 33 \\
\hline 5 & $\mathrm{~F} / 65$ & 9 & $\begin{array}{l}\text { Ampicillin (oral), penicillin (top. }+ \text { oral), } \\
\text { chloramphenicol (top.) }\end{array}$ & 6 \\
\hline 6 & $\mathrm{M} / 41$ & 6 & $\begin{array}{l}\text { Genticin (top.) (Nicholas), Fucithalmic (top.) (Leo), } \\
\text { indomethacin (oral), penicillin (top.) }\end{array}$ & 5 \\
\hline 7 & $\mathrm{~F} / 71$ & 3 & Zinc and adrenaline (top.) & 96 \\
\hline
\end{tabular}

top., topical. ${ }^{\mathrm{a}}$ No. of visits = all clinic/casualty visits before surgery. ${ }^{\mathrm{b}}$ Treatment given in most cases without considering Actinomyces as the diagnosis.

affected only one canaliculus in all our cases, but in the literature simultaneous involvement of both upper and lower canaliculi has been reported. ${ }^{3,8,9}$

The duration of symptoms before these patients first presented to us averaged 13 months. All had a patent lacrimal drainage system on syringing. Despite the chronicity of symptoms and typical patency of the lacrimal drainage system to syringing, ${ }^{5,10,11}$ the diagnosis of Actinomyces canaliculitis was overlooked. We feel that in any patient with epiphora, irritation, and discharge from the

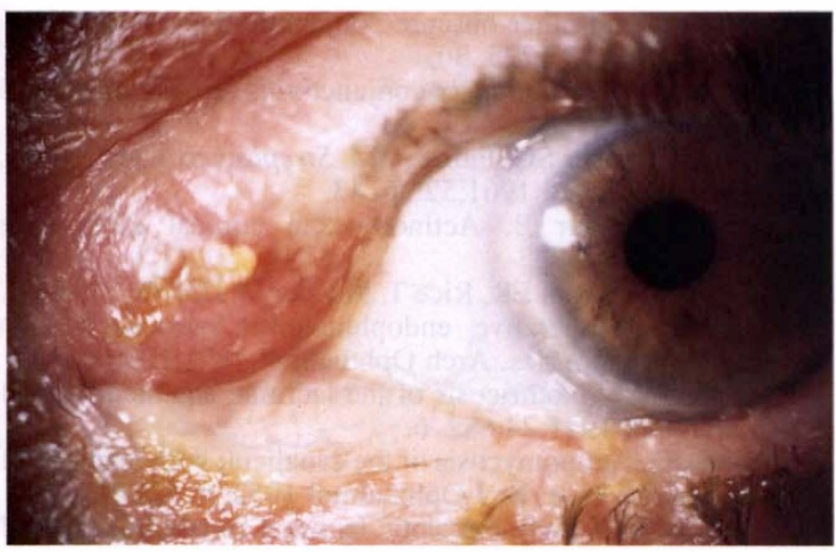

Fig. 1. Upper canalicular involvement with Actinomyces.

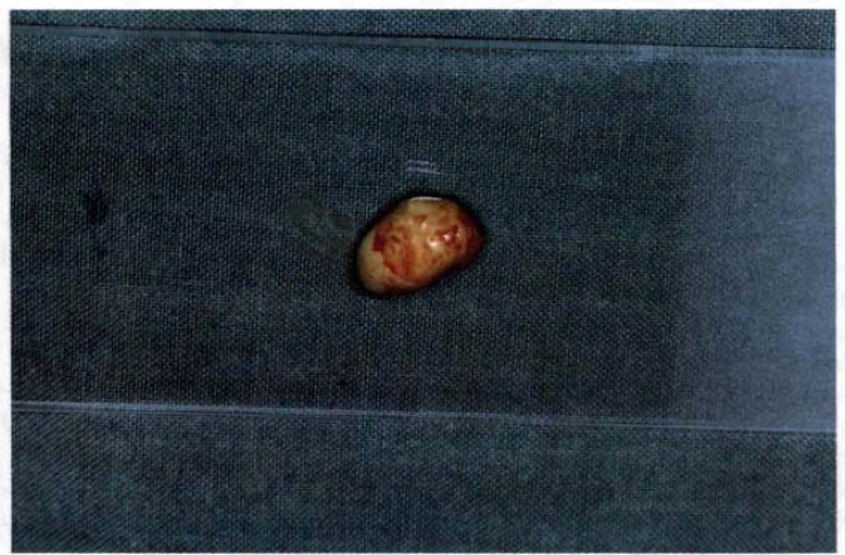

Fig. 3. A canalicular concretion (approx. $9 \times 5 \mathrm{~mm}$ ). punctum of long duration and patency to syringing, Actinomyces should be considered. Patients may or may not present with a canalicular swelling.

Actinomyces are usually difficult to grow from routine conjunctival eye swabs ${ }^{5}$ and therefore they are not ideal specimens. Indeed, although in 4 of our cases a preoperative swab was taken with a specific request to culture for Actinomyces, in only 1 case was a positive identification possible (patient 5 ). Therefore, as much discharge as possible should be placed in a sterile pot and transported to the

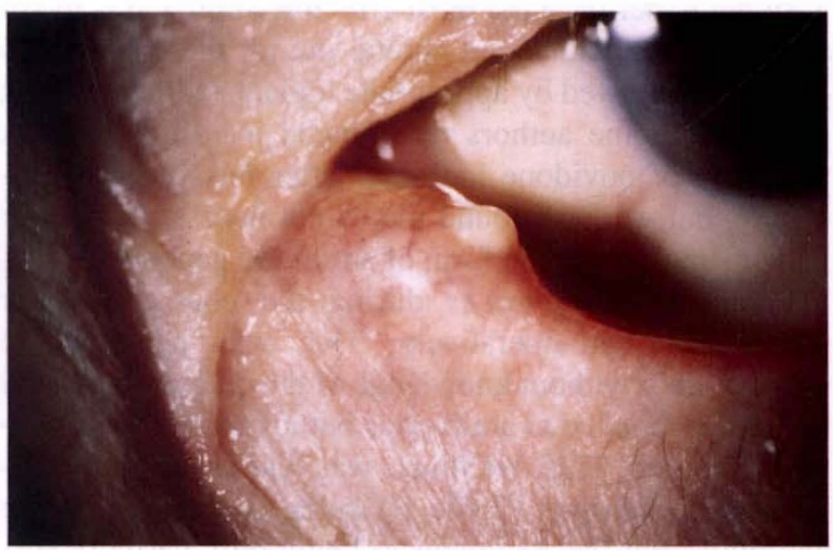

Fig. 2. A pouting punctum and discharge, with patency to syringing, is typical of Actinomyces canaliculitis.

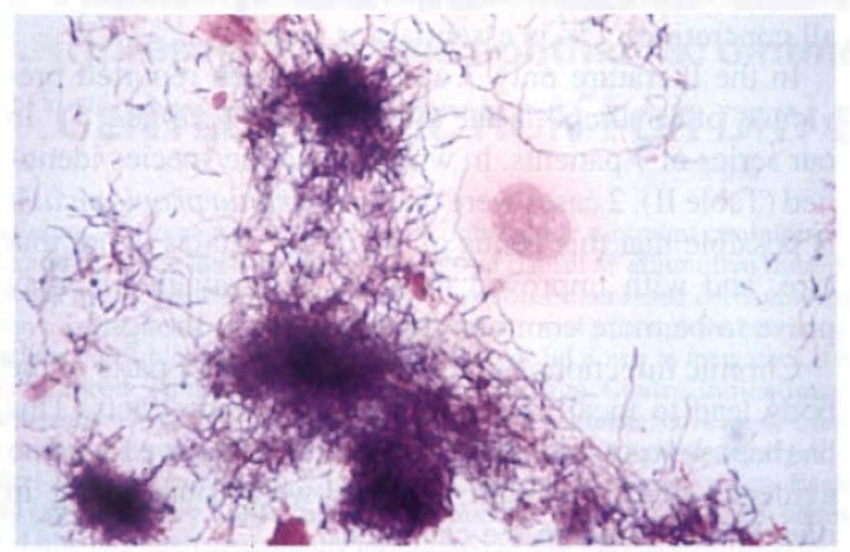

Fig. 4. Gram staining showing filamentous Actinomyces. $\times 40$ 
Table II. Microbiological results

\begin{tabular}{|c|c|c|c|}
\hline Patient no. & $\begin{array}{l}\text { Associated bacteria } \\
\text { grown with Actinomyces }\end{array}$ & $\begin{array}{l}\text { Actinomyces } \\
\text { species }\end{array}$ & $\begin{array}{l}\text { Antibiotic } \\
\text { sensitivity }\end{array}$ \\
\hline 1 & $\begin{array}{l}\text { Eikenella corrodens, Haemophilus parainfluenzae, } \\
\text { Peptostreptococcus } \mathrm{sp} \text {. }\end{array}$ & A. israelii & Not known \\
\hline 2 & $\begin{array}{l}\text { Peptostreptococcus sp., Haemophilus influenzae } \\
\text { ( } \beta \text {-lactamase producer) }\end{array}$ & Not known & Not known \\
\hline 3 & Peptostreptococcus sp. & A. meyeri & $\begin{array}{l}\text { Penicillin, tetracycline, } \\
\text { erythromycin }\end{array}$ \\
\hline 4 & $\begin{array}{l}\text { Streptococcus milleri, Corynebacterium sp., Pep- } \\
\text { tostreptococcus } \mathrm{sp} \text {. }\end{array}$ & A. israelii & $\begin{array}{l}\text { Penicillin, tetracycline, erythromycin, } \\
\text { chloramphenicol }\end{array}$ \\
\hline 5 & $\begin{array}{l}\text { Fusobacterium sp., E. corrodens, Corynebacterium } \\
\text { sp., Peptostreptococcus sp. }\end{array}$ & Arachnia propionica & $\begin{array}{l}\text { Penicillin, erythromycin, tetracycline, } \\
\text { chloramphenicol }\end{array}$ \\
\hline 6 & Fusobacterium nucleotum, Bacteroides corrodens & Arachnia propionica & Penicillin, erythromycin, tetracycline \\
\hline 7 & None & A. israelii & $\begin{array}{l}\text { Penicillin, chloramphenicol, } \\
\text { erythromycin }\end{array}$ \\
\hline
\end{tabular}

microbiology department without delay, to ensure optimal conditions for isolation of Actinomyces species.

Various forms of treatment have been recommended for this condition in the past. Medical therapy includes irrigation of the involved canaliculus with penicillin, ${ }^{9,10}$ but this has not been found to be effective. Indeed this was performed in patient 5 with little benefit. Simple mechanical expression of concretions or curetting them after dilatation of punctum can be ineffective in removing all the concretions, as some are fairly large. ${ }^{10}$

In our experience the most effective approach is to slit open the canaliculus and curette out all the concretions carefully, followed by appropriate topical and/or systemic antibiotic. Some authors recommend instilling aqueous penicillin or povidone iodine $e^{3,5,8}$ after this surgical procedure, but we have found this is not necessary. All our patients received some form of antibiotic generally effective against Actinomyces during the course of their management pre-operatively. This was administered either with or without knowledge of the diagnosis. All the patients responded to antibiotics but invariably the symptoms returned. This, we think, was due partly to the coinfecting organisms (Table II) being susceptible to the antibiotics but the Actinomyces being only partially susceptible; treatment therefore did not result in eradication of Actinomyces, perhaps due to failure of the drug to penetrate concretions. In our experience surgical removal of all concretions ${ }^{3,10,11}$ is essential for a cure.

In the literature only 7 cases have been reported previously of canaliculitis due to Arachnia propionica. ${ }^{13-18}$ In our series of 7 patients, in which 6 had the species identified (Table II), 2 cases were due to Arachnia propionica. It is possible that this genus of Actinomycetales is not that rare, and with improved methods of speciation it may prove to be more common than previously thought.

Chronic infections by Actinomyces in other parts of the body lead to local invasion producing sinus tracts. This has been reported in canalicular infection ${ }^{9}$ but we found no evidence of it, although granules were found lying in diverticuli formed in the canaliculi.

It is likely that these organisms gain entry to the canaliculi by either regurgitation from the oral cavity, or direct inoculation by saliva ${ }^{12}$ or some other means, as Actinomyces are not found as normal commensals ${ }^{19}$ of the lacrimal drainage system.

Key words: Actinomyces, Canaliculitis.

\section{REFERENCES}

1. Harz CO. Actinomyces bovis: ein neuer Schimmel in den Geweben des Rindes. Dtsch Z Tier-Med 1879;5(suppl): 125-40.

2. Ridley F, Smith C. Leptotrichosis conjunctivae. Br J Ophthalmol 1952;36:328-9.

3. Theodore FH. Streptothrix as a cause of follicular conjunctivitis and other obscure conjunctivitides. Am J Ophthalmol 1950;33:1225-30.

4. Greeves RA. Streptothrix conjunctivitis. Br J Ophthalmol 1952;36:653.

5. Ellis PP, Bausor SC, Fulmer JM. Streptothrix canaliculitis. Am J Ophthalmol 1961;52:36-43.

6. Singh M, Kaur B. Actinomycetic corneal ulcer. Eye 1989;3:460-2.

7. Roussel TJ, Olson ER, Rice T, Meisler D, Hall G, Miller D. Chronic postoperative endophthalmitis associated with Actinomyces species. Arch Ophthalmol 1991;109:60-2.

8. Elliot AJ. Streptothricosis of the lacrimal canaliculi. Am J Ophthalmol 1941;24:682-6.

9. Moore JG. Actinomycosis of the canaliculi with invasion of tissue in one case. Br J Ophthalmol 1952;36:522-4.

10. Richards WW. Actinomycotic lacrimal canaliculitis. Am J Ophthalmol 1973;75:155-7.

11. Ruys AC. Concretions in a lacrymal canaliculus caused by Actinomyces. Br J Ophthalmol 1935;19:385-9.

12. Pine L, Hardin H, Turner L, Roberts SS. Actinomycotic lacrimal canaliculitis. Am J Ophthalmol 1960;49:1278-88.

13. Buchanan BB, Pine L. Characterisation of a propionic acid producing actinomycete, Actinomyces propionicus, sp.nov. J Gen Microbiol 1962;28:305-23.

14. Gerencser MA, Slack JM. Isolation and characterisation of Actinomyces propionicus. J Bacteriol 1967;94:109-15.

15. Brock DW, Georg LK, Brown JM, Hicklin MD. Actinomycosis caused by Arachnia propionica. Am J Clin Pathol 1973;59:66-77.

16. Jones DB, Robinson NM. Anaerobic ocular infections. Trans Am Acad Ophthalmol Otolaryngol 1977;83:309-31.

17. Seal DV, McGill J, Flanagan D, Purrier B. Lacrimal canaliculitis due to Arachnia (Actinomyces) propionica. $\mathrm{Br} \mathrm{J}$ Ophthalmol 1981;65:10-3.

18. Ishii F, Oyamada Y, Shimada M, Ohtaki S. A case of lacrimal canaliculitis due to Arachnia propionica. Folia Ophthalmol Jpn 1982;33:1969-72.

19. Pine L, Shearin WA, Gonzales CA. Mycotic flora of the lacrimal duct. Am J Ophthalmol 1961;52:619-25. 